\title{
Health systems, policies and infant mortality in developing countries
}

\author{
David Baguma*, Jamal Hisham Hashim, Syed Mohamed Aljunid \\ From 6th Postgraduate Forum on Health Systems and Policies \\ Melaka, Malaysia. 21-22 May 2012
}

\section{Background}

The global movement to improve the quality of life advances the role of health systems and their policies to reduce challenges faced such as health risks caused by climate change and environmental hazards. In this paper, we focus on infant mortality and examine the status of the infant mortality between birth and one year age in developing countries.

\section{Methods}

The secondary data on infant mortality was obtained on countries in Eastern Africa, Western Europe and Southern Asian countries between 1950 and 2010 expressed as deaths per 1,000 births. Countries in Western Europe were used for comparison purposes. The data also included inpatients (admissions and deaths in 2007) of water-related diseases such as malaria and diarrhoea, in Eastern Africa (i.e., Uganda). Nonlinear regression modelling was utilized in the empirical analysis.

\section{Results}

The study shows that, children deaths between birth and age one had declined in Eastern Africa by 7\%, Western Europe by $23 \%$ and reduced by $15 \%$ in Southern Asian countries. The study also shows that the Eastern African countries require more than 50 years to improve infant mortality to levels close to Western Europe countries (i.e., $3.52>3.6)$, ceteris-paribus.

\section{Conclusion}

Inadequacies in the health systems, climate change linked health risks, low national incomes and waterrelated diseases are partly some of the causes of high

United Nations University International Institute for Global Health, Universiti Kebangsaan Malaysia Medical Centre, Jalan Yaacob Latiff, 56000 Kuala Lumpur, Malaysia infant mortality in which policy measures could emphasize for global health interventions.

Published: 27 November 2012

doi:10.1186/1471-2458-12-S2-A23

Cite this article as: Baguma et al:: Health systems, policies and infant mortality in developing countries. BMC Public Health 2012 12(Suppl 2): A23.
Submit your next manuscript to BioMed Central and take full advantage of:

- Convenient online submission

- Thorough peer review

- No space constraints or color figure charges

- Immediate publication on acceptance

- Inclusion in PubMed, CAS, Scopus and Google Scholar

- Research which is freely available for redistribution
C Biomed Central
C Biomed Central

ㄷ 2012 Baguma et al; licensee BioMed Central Ltd. This is an Open Access article distributed under the terms of the Creative Commons Attribution License (http://creativecommons.org/licenses/by/2.0), which permits unrestricted use, distribution, and reproduction in any medium, provided the original work is properly cited. 